\title{
"The next generation of cultivators": teaching agriculture in Iraq, Palestine and Transjordan (1920-1960)
}

"Former la génération suivante des cultivateurs": l'enseignement agricole en Irak, Palestine et Transjordanie (1920-1960)

Hilary Falb Kalisman

\section{(2) OpenEdition}

Electronic version

URL: https://journals.openedition.org/histoire-education/3653

DOI: 10.4000/histoire-education.3653

ISSN: 2102-5452

\section{Publisher}

ENS Éditions

\section{Printed version}

Date of publication: 31 December 2017

Number of pages: 143-164

ISSN: 0221-6280

\section{Electronic reference}

Hilary Falb Kalisman, "'The next generation of cultivators": teaching agriculture in Iraq, Palestine and

Transjordan (1920-1960)", Histoire de l'éducation [Online], 148 | 2017, Online since 31 December 2020, connection on 20 May 2021. URL: http://journals.openedition.org/histoire-education/3653 ; DOI:

https://doi.org/10.4000/histoire-education.3653 


\title{
"The next generation of cultivators": teaching agriculture in Iraq, Palestine and Transjordan (1920-1960)
}

\author{
Hilary Falb Kalisman
}

Agriculture was the key economic sector of Iraq, Palestine and Transjordan/ Jordan during the first half of the $20^{\text {th }}$ century. Locals and colonial administrators touted increasing agricultural productivity as indispensable for Mandate societies. They emphasized education as one of the most important ways of improving agriculture and the status of cultivators overall. British and Jewish narratives of development went a step further, linking the ability to modernize agriculture with the right to rule ${ }^{1}$.

Historians have analyzed agricultural education's goals and outcomes in individual Middle Eastern Mandates. They describe agricultural education as a site where policymakers and local populations contested educational ideals, as well as nationalism ${ }^{2}$. There is a vast literature on agriculture and education

1 Jacob Norris, Land of Progress: Palestine in the Age of Colonial Development, 1905-1948, Oxford, Oxford University Press, 2013.

2 Elizabeth Williams, "Contesting the Colonial Narrative's Claims to Progress: A Nationalist's Proposal for Agrarian Reform", Review of Middle East Studies, 44, no. 2, 2010, p. 187-195, p. 192; Sara Pursley, "Building the Nation through the Production of Difference", in Jordi Tejel Gorgas and Riccardo Bocco (ed.), Writing the Modern History of Iraq: Historiographical and Political Challenges, London/ Singapore, World Scientific, 2012, p. 119-141, p. 132; Estie Yankelevitch, Heyeh Shalom Mar Fiat: 
concentrating on the Yishuv (Palestine's immigrant Jewish community) and Israel. This historiography has traced how Israeli nationalist narratives of "making the desert bloom" drew on modernizing rhetoric to justify the control of the land ${ }^{3}$. However, this paper concentrates on government and Arab education. Employing a regional and comparative perspective, I argue that instead of improving agricultural productivity, agricultural schooling across Britain's Mandates represented an alternative to farming, promising a career in teaching as well as in government service. Independent governments incorporated Mandate-era agricultural education while deploying an intensified rhetoric of development and modernization.

Analyzing state-sponsored agricultural education across multiple countries and regimes reveals trends in schooling and farming, as well as shifting relationships between government schooling of any sort and government employment. The borders of the three countries under investigation were newly carved from Ottoman provinces; their people often crossed between each state. Climates, populations, levels of urbanization, and politics differed. Treating each Mandate and subsequent state as a distinct unit allows for efficient comparison, but exaggerates their discrete coherence: textbooks, pedagogical concepts, and educators circulated throughout ${ }^{4}$.

Agricultural education expanded worldwide from the $19^{\text {th }}$ century onward. Increasingly powerful and intrusive states supported vocational education

Natan Fiat U-Vet Ha-Sefer Ha-Haklai Kaduri Har Tabor 1937-1959 (Goodbye Mr. Fiat: Nathan Fiat and the Kadoorie Mount Tabor Agricultural School 1937-1959), Tel Aviv, Tel Aviv University, 2013; Estie Yankelevitch, "Twins Separated at Birth: The Mandate Agricultural Schools named Kadoorie" (Teumim shehofradu b'lidatam: mimshelat hamandat v'batei sefer haHaklai'im al-shem Kadoorie), Israel: Studies in Zionism and the State of Israel-History, Society, Culture, no. 24, 2016, p. 213; Roza I. El-Eini, "British Agricultural Educational Institutions in Mandate Palestine and Their Impress on the Rural Landscape”, Middle Eastern Studies, 35, no. 1, 1999; Roza El-Eini, Mandated Landscape: British Imperial Rule in Palestine, 1929-1948, London, New York, Routledge, 2006. One of the few exceptions is Elizabeth Williams, "Mapping the cadastre, producing the fellah: technologies and discourses of rule in French mandate Syria and Lebanon" in Cyrus Schayegh, Andrew Arsan (dir), The Routledge Handbook of the History of the Middle East Mandates, London, Routledge/Taylor \& Francis, 2015, p. 170-182.

3 See Alan George, "Making the Desert Bloom: a Myth Examined", Journal of Palestine Studies, vol. 8, no. 2, 1978/9, p.88-89.

4 For a discussion of the implications, pitfalls and counter examples to analyzing each Mandate on its own see Cyrus Schayegh, "The Many Worlds of "Abud Yasin or, What Narcotics Trafficking in the Interwar Middle East Can Tell Us about Territorialization”, The American Historical Review, 116, no. 2, 2011, p.273-306. Similarly, Robert S.G. Fletcher describes transnational administrators, air and land routes, and the relationship between expertise and how the desert was administered: Robert S.G. Fletcher, British Imperialism and 'The Tribal Question': Desert Administration and Nomadic Societies in the Middle East, 1919-1936, Oxford, Oxford University Press, 2015, p. 71-72 and 81-84. 
(including agricultural schooling) as a means of training workers: an alternative to academic education. From the rural schools of France to American and Ottoman agricultural colleges, governments hoped to tailor education to students' needs while fitting government schooling to the needs of each country's economy ${ }^{5}$. British colonial officials sought to make agriculture more productive empire-wide, while taking care to educate students, "in such a manner that their ambitions would not run ahead of their social position" ${ }^{\prime \prime}$. The Mandateera's colonial governments, Iraq's post-independence dictators and Jordan's little-changing ruling cadre hoped agricultural schooling would maintain political stability through an urban/rural divide, while improving each country's economy. However, mundane and political considerations blunted the intended effects of agricultural teaching.

Without first-hand accounts, diaries, memoirs or oral histories, the relationship of official descriptions to what took place within classrooms on a dayto-day basis in the past is often difficult to determine ${ }^{7}$. Yet, even very general descriptions of agricultural instruction that concentrate on the aggregate outcomes of educational policies rather than students' daily socialization, raise questions about how policy-makers and participants instrumentalized schooling.

The expansion of education in Iraq, Palestine and Transjordan/Jordan, from the 1920s through the end of the 1950s, regardless of its form or focus, promised better employment for those who could obtain it. Government agricultural education in particular targeted rural communities offering a new path of advancement for a select few. In the process, Iraqis, Palestinians and Jordanians left rural areas and farms for classrooms, emerging as teachers and civil servants.

5 James Ralph Jewell, Agricultural Education, Including Nature Study and School Gardens. Washington, Govt. Print. Off, 1907, p. 48-49; Howard R. D. Gordon, The History and Growth of Career and Technical Education in America, Long Grove, Ill, Waveland Press, 2008, p. 106-107; Donald Quataert, "Ottoman Reform and Agriculture in Anatolia, 1876-1908”, Los Angeles, University of California Press, 1973, p. 92-108.

6 Carl C. Campbell, The Young Colonials: A Social History of Education in Trinidad and Tobago, 18341939, Barbados, Press University of the West Indies, 1996, p.78-81.

7 In Egypt, as opposed to Britain's Mandates, autobiographies demonstrate how wealthier rural parents sought to prevent their educated, effendi sons from fleeing careers in agriculture for further study and bureaucratic posts. Lucie Ryzova, The Age of the Efendiyya: Passages to Modernity in NationalColonial Egypt, Oxford, Oxford University Press, 2014, p. 112. 


\section{Background and Context}

During World War I, the British and French military administrations assumed responsibility for public education in the former Arab Provinces of the defeated Ottoman Empire, in accordance with the Hague Conventions regarding military occupation. British control over schooling varied greatly, across territories and over time. The British allowed Iraqi citizens to hold high-ranking posts in the Department and later Ministry of Education as a concession to Iraqi independence. As a result, although Iraq's independence was in many ways nominal, with the end of the Iraqi Mandate in 1932, the British retained little influence over education, other than a brief interlude during the Second World War ${ }^{8}$. In Transjordan, non-British officials ran a very limited school system, restricted by a British-controlled budget. In the Mandate for Palestine, British civil servants led the Department of Education, while Arabs held the majority of positions in the Department.

Mandate administrations had a variety of motivations for improving agricultural education, and agricultural productivity. Local officials hoped to better their societies (and often themselves) through agricultural schooling. They advocated agricultural training as a means of modernization, at times taking the Mandate governments to task for failing in this mission ${ }^{9}$. The Yishuv viewed agricultural improvements as a sign of fitness to control the land, and as a negation of diaspora images of bookish, wandering Jews ${ }^{10}$.

Higher agricultural output meant more revenue, whether in coin or in kind. The Mandates themselves were meant to be self-sustaining, using local

8 Education was less strictly controlled than other spheres of government and foreign policy, deemed crucial particularly defense, or rather, defense of British interests. Priya Satia, Spies in Arabia: The Great War and the Cultural Foundations of Britain's Covert Empire in the Middle East, Oxford, Oxford University Press, 2008, p. 261.

9 Matta Akrawi, Curriculum Construction in the Public Primary Schools of Iraq in the Light of a Study of the Political, Economic, Social, Hygienic and Educational Conditions and Problems of the Country, with Some Reference to the Education of Teachers. A Preliminary Investigation, Teachers' College Columbia University, 1942, p. 200; Hassan Abdulrazzak Kufaishi, "Education as a Vehicle for National Development in Iraq", Teachers' College Columbia University, 1977, p. 4-77; Abdul Latif Tibawi, Arab Education in Mandatory Palestine: A Study of Three Decades of British Administration, London, Luzac, 1956, p. 35; Al Kulliya, vol. 16, no. 4, February 1930, p. 132; Maan Abu Nowar, The Development of Trans-Jordan 1929-1939: A History of the Hashemite Kingdom of Jordan, Reading, Ithaca Press, 2006, p. 164; Abdulqadir Mohammad Yousuf, The British Educational Policy in the Arab Public Schools of Palestine During the Mandate, Bloomington, Indiana University Press, 1956, p. 133-134.

10 Derek Jonathan Penslar, Zionism and Technocracy: The Engineering of Jewish Settlement in Palestine, 1870-1918, Bloomington, Indiana University Press, 1991, p. 89. 
sources of funding rather than those of British taxpayers ${ }^{11}$. The British sought to increase tax revenue to support the Mandate administrations and, if possible, to promote political stability ${ }^{12}$. For instance, Transjordan's government implemented policies that benefitted local cultivators, in the hope of increasing agricultural output while dissuading peasant rebellion ${ }^{13}$. On a more ideological level, British officials asserted they would bring modern agriculture to the region, thereby furthering their mission to develop the Mandates and civilize their inhabitants ${ }^{14}$.

Regardless of local or British assertions, political, strategic, and economic considerations hampered the results of agricultural initiatives. Implementing large-scale educational and agricultural reforms required funding, which colonial governments doled out parsimoniously to the local population ${ }^{15}$. The Arab Palestinian community mostly gained their livelihood from agriculture. They faced natural disasters such as locusts and drought, as well as difficulties due to money lending, land ownership structures, and the procedures implemented to sell land to the Yishuv. Despite overall increases in agricultural productivity in Mandate Palestine, higher taxes, rents, and the sale of land to Zionist organizations forced Arab cultivators from their farms and into wage labor, thereby lessening farming's appeal ${ }^{16}$. Transjordan's government lacked funding, and therefore agricultural initiatives. However, Transjordanian students studied abroad, advancing their own careers if not necessarily their country's agricultural development. In Iraq, British policies promoted the interests of particular sheikhs, concentrating landholding in the hands of fewer and fewer individuals and imposing a type of feudalism, tying cultivators to land they did

11 Phyllis Maslow, Economic Development of Iraq, 1914-1932, PhD, University of Chicago, 1951, p. 101.

12 In Palestine, and presumably Iraq, British taxpayers funded British troops. Henry Gurney, and Motti Golani, The End of the British Mandate for Palestine, 1948: The Diary of Sir Henry Gurney, Basingstoke, Palgrave Macmillan, 2009, p. 91-92.

13 Tariq Tall, "Nomads, Peasants and the State in Jordan: the Politics of Rural Policy" in Martha Mundy, Basim Musallam (ed.), The Transformation of Nomadic Society in the Arab East, Cambridge, Cambridge University Press, 2000, p. 94.

14 League of Nations, "The Covenant of the League of Nations Including Amendments Adopted to December, 1924", Champaign, Ill.; Boulder, Colo., Project Gutenberg; NetLibrary, 1924. Article 22.

15 The amount of funding devoted to education in the British Mandates including Palestine hovered between 5 and $7 \%$ of each government's budget. By the 1950s, and the end of the Mandates for Jordan and Iraq, educational funding jumped to almost $10 \%$ and nearly $25 \%$ respectively. Hilary Falb Kalisman, Schooling the State: Educators in Iraq, Palestine and Transjordan: c. 1890-c. 1960, $\mathrm{PhD}$, University of California at Berkeley, 2015, p. 157.

16 Issa Khalaf, "The Effect of Socioeconomic Change on Arab Societal Collapse in Mandate Palestine", International Journal of Middle East Studies, 29, no. 1, 1997, p.93-97. 
not own. The power of landowners undermined attempts to improve agriculture, simultaneously reducing the lifespan of Iraqi cultivators ${ }^{17}$.

When Iraq, Jordan and Israel achieved greater degrees of independence, their governments shifted funds towards agricultural education. During the 1950s, agriculture as well as agricultural schooling became more specialized. Strengthened governments began to rely on other sources of income, yet agriculture often remained a subject of study at elementary or primary levels. Israel's almost excessive "aggrandizement" of agriculture, as a way of countering the diasporic Jewish condition began to lessen as urbanization increased ${ }^{18}$. Yet, as this idealization of agriculture decreased Israel's government still made a concerted effort to offer agricultural training in elementary schools. They also created and supported as intermediate, secondary and college-level agricultural institutions, even if these specialized institutions did not produce as many farmers as desired ${ }^{19}$.

After the end of the Mandates, Jordan and Iraq's Hashemite administrations implemented new policies, deploying the most modern methods of agriculture in order to improve agricultural productivity. By the 1940s, many of Iraq's ministers had sought to implement various agricultural schemes, but they faced obstruction on the part of Iraq's landowners ${ }^{20}$. When Iraqis did adopt these programs, policies did not necessarily achieve the intended results: for example, incentives for local investment in mechanized irrigation altered soil salinity, decreasing agricultural productivity in newly-irrigated areas ${ }^{21}$. Oil supplanted agriculture in the government's priorities during the 1950s: by 1954 , agriculture supplied only $3 \%$ of the government's revenue ${ }^{22}$. Despite agriculture's diminishing importance for government revenue, agriculture was included as a subject in rural schools, while urban students studied gardening ${ }^{23}$.

17 Haim Gerber, The Social Origins of the Modern Middle East. Boulder, L. Rienner, 1987, p. 93-94; Hanna Batatu, The Old Social Classes and the Revolutionary Movements of Iraq: A Study of Iraq's Old Landed and Commercial Classes and of Its Communists, Ba Thists, and Free Officers, New Jersey, Princeton University Press, 2004, p. 140-148.

18 Zvi Zamaret, Fifty Years of Education in the State of Israel, Jerusalem, Israel Information Center, 1998.

19 Aharon F. Kleinberger, Society, Schools and Progress in Israel, Oxford, Pergamon Press, 1969, p. 174, 196 and 225-226.

20 Joseph Sasson, Economic Policy in Iraq: 1932-1950, London, Routledge, 2012, p. 155.

21 Charles Tripp, A History of Iraq, New York, Cambridge University Press, 2010, p. 69.

22 Ibid. p. 138.

23 International Bureau of Education, Unesco, International Yearbook of Education, 1953, Vol. 15, Paris/Genève, Unesco, 1954, p. 568. 
In Jordan, agriculture represented 40\% of the country's GDP in the 1950s but declined to $17 \%$ before the 1967 war $^{24}$. The Hashemite-run, foreign-supported Jordanian government needed to create jobs, particularly in agriculture in order to maintain political stability in the wake of the tremendous increase in its' Palestinian population after the 1950s. The government opened new agricultural institutions and adopted new policies, directed by various aid organizations, that increased irrigation and offered rewards for land redistribution ${ }^{25}$. At the same time, Jordan's government elites pushed reforms that benefitted their own interests, improving commercial farming on a large scale, while forcing peasants and smallholders into state or eventually service sector employment ${ }^{26}$.

As education expanded, it offered a way out of farming for ambitious young men and women. Increasingly expansive and intrusive governments sought to break this automatic connection between state schooling and state formation. Through the 1950s however, government education, whether agricultural or academic, tended to attract each country's citizens with the promise of government careers, thus disrupting the urban/rural divide.

\section{Teaching Agriculture}

Many of the scant but growing numbers of school-age children in the Mandates who attended any type of institution would have received some form of agricultural education. This ranged from a few hours per week of agricultural instruction in elementary schools, to a full course in practical agriculture at a secondary level, to raising beans in a school garden. Schooling allowed students to improve their social and economic station, obtaining while-collar jobs as clerks, teachers, bureaucrats and other civil servants. Agriculture was among the subjects students were required to pass in order to advance educationally and professionally.

While British and American-trained Iraqi officials advocated agricultural and "practical" schooling, the Ottoman-Arab official in charge of Iraq's education

24 International Business Publications, Jordan Country Study Guide Strategic Information and Developments, International Business Publications, USA, 2012, p. 197.

25 Munther J. Haddadin, "Evolution of Water Administration and Legislation" in Clive Lipchin, Deborah Sandler and Emily Cushman (eds.), The Jordan River and Dead Sea Basin, Dordrecht, Springer Netherlands, 2009, p. 42-48.

T. Tall, "Nomads, Peasants and the State in Jordan", art. cit., p. 96-98. 
during much of the 1920s prioritized Arabic and courses that promoted Arab nationalism over agricultural training. He argued (presciently) that teaching schoolchildren farming methods was insufficient to improve agriculture in Iraq overall $^{27}$. The result of these academic and nationalist vs. vocational debates was that Hashemite-era syllabi included agriculture as an academic subject. Growing numbers of students memorized agricultural information in order to pass examinations, advancing in education rather than farming. The numbers of elementary school students in government schools increased with the power of the Iraqi state: 7400 in the 1920-21 school year, 38400 in 1932, and 500000 in $1958^{28}$. In 1932 a little over 2000 students were in intermediate and preparatory-level schools, approximately 11000 in 1944, and 103000 in 196029.

The British military administration had included agricultural instruction in the third and fourth years of elementary school, but after 1923, and a decline of British control, agriculture was assigned only in a historical and religious context, and through object lessons ${ }^{30}$. The primary school syllabus finalized in 1928 noted that object lessons ought to impart "hygienic, agricultural and technical information that no one can do without". This information, particularly in the second through fourth grades included "plowing, fertilizing, planting, harvesting, threshing, irrigation... [and] principles of raising the most important local vegetables, cereals and trees..." ${ }^{31}$. In 1943, the elementary school syllabus similarly included "the rudiments of agriculture" in object lessons and in ancient history ${ }^{32}$, while the intermediate school syllabus proscribed "agriculture and manufacturing" along with "cleanliness and courage, anger and justice,

27 Sara Pursley, "Education for Real Life: Pragmatist Pedagogies and American Interwar Expansion in Iraq", in The Routledge Handbook of the History of the Middle East Mandates, p. 93; Abu Khaldun Sati Husri, Mudhakkirati Fi Al-'Iraq Al-Juz' Al-Thānī: 1927-1941, Beyrout, Dār al-Ṭalīah lil-Ṭibāah wa-al-Nashr, 1968, p. 186-188.

28 Roderic D. Matthews, Matta Akrawi, Education in Arab Countries of the near East: Egypt, Iraq, Palestine, Transjordan, Syria, Lebanon, Washington D.C., American Council on Education, 1949, p. 140; Ministry of Education Iraq, Wizarat al-Ma'arif Iraq, Annual Report [on] Educational Statistics 19461947 Taqrir Al-Sanawi, Al-Ihsa Al-Tarbawi, Bagdad, Ministry of Education, 1947, p. 34; Wizarat al-Ma'arif, Ministry of Education: Educational Statistics, Annual Report 1960-61. Taqrir Al-Sanawi, Al-Ihsa Al-Tarbawi, Bagdad, Ministry of Education, 1961, p. 117.

29 Ministry of Education Iraq, Wizarat al-Ma'arif Iraq, Annual Report [on] Educational Statistics 19461947, Taqrir Al-Sanawi, Al-Ihsa Al-Tarbawi, p. 34, Taqrir Al-Sanawi, Al-Ihsa Al-Tarbawi, 1961, p. 117.

30 Department of Education, Government Schools of Iraq, Syllabus of the primary course of study", Bagdad, Government Press, 1919. The British Library, BL India Office Records, IOR/L/PS/10/816. File 1454/1919 Education in Mesopotamia.

31 "Curriculum Construction in the Public Primary Schools of Iraq", art. cit., p. 189.

32 Roderic D. Matthews and Matta Akrawi, Education in Arab Countries of the near East, op. cit. p. 151. 
truth and lies..." in one hour per week of religious lessons ${ }^{33}$. In $7^{\text {th }}$ to $9^{\text {th }}$ grade, students also learned about agriculture in history (the agricultural practices of the Ancient Greeks) ${ }^{34}$.

Rudiments of agriculture, references to agriculture in history, and object lessons, required students to memorize concepts related to agriculture, in order to pass Iraqi government examinations, as opposed to actually practicing agriculture. Representations took precedence over their application. Agriculture was flattened into an academic subject, which inevitably distanced students from agricultural practice, both mentally and physically ${ }^{35}$. Passing exams allowed students from rural or urban areas to gain access to upper levels of Iraqi schooling, and through schooling, to employment ${ }^{36}$. Into the independence period, government education tended to focus on academic subjects rather than agriculture, particularly once it had become a less defining feature of the Iraqi economy. By 1960, references to agriculture in the primary school syllabus were erased. "General life information" or "object lessons and hygiene" courses after 1960 may have included agriculture, but in Iraq's preparatory and intermediate schools, agriculture had disappeared from the curriculum ${ }^{37}$.

In contrast to Iraq's diminution of agricultural study, Palestine's emphasis on agriculture in elementary government schools increased over the Mandate period, as colonial policymakers as well as some local intellectuals and notables sought to improve the lot of the fellahin, as well as to stem the rising tide of urbanization. The number of government school students grew from 11000 overall in 1920, to 19000 elementary school students in $1925,77,000$ by $1946^{38}$. Town schools did not assign agriculture, but teachers were encouraged to develop school gardens and agricultural instruction if time and space allowed. In addition, students could

33 The Ministry of Education of Iraq, Syllabus of the Intermediate School, Bagdad, Government Press, 1931, p. 3, 5, 20.

34 Syllabus of the Intermediate School, p. 3, 20.

35 Anees Adil, "Recommendations and Proposals for a Science Program for the First Nine Grades Based on the Individual and Social Needs of the People of Iraq", Teachers College Columbia University, 1937, p. 20. This abstracting of agriculture parallels Timothy Mitchell's analysis of land and nature. Timothy Mitchell, Rule of Experts: Egypt, Techno-Politics, Modernity, Berkeley, The University of California Press, 2002.

36 Abdul Hamid Kadhim, A Plan for the Reconstruction of Teacher Education in Iraq, Teachers College Columbia University, 1947, p. 28.

37 Taqrir Al-Sanawi, Al-Ihsa Al-Tarbawi 1961, p. 13, 31.

38 Roderic D. Matthews, Matta Akrawi, Education in Arab Countries of the Near East, op. cit., p. 236; Government of Palestine Department of Education, Annual Report 1945-46, Jerusalem, 1947, p.6; Government of Palestine Department of Education Annual Report 1924-1925 Jerusalem, 1926, p. 27. 
compete with one another to produce the best garden plot $^{39}$. In order to counter the lure of the city, policymakers promoted a more rural and agricultural bias in village elementary schools, which offered four 45-minute periods of agricultural instruction and handiwork weekly in the second and third year ${ }^{40}$. Despite the government's intentions to keep the population rural, the two best-performing students in each Arab government school were admitted, free of charge, to the Arab College of Jerusalem, the top Government school in the Mandate for Palestine, where they would train to be teachers or go on to higher education. This meant paradoxically success in agricultural lessons and in schooling overall granted rural children an avenue towards white-collar work. Approximately two-thirds of the College's students were from rural areas ${ }^{41}$.

As in Palestine and Iraq, government schooling in Transjordan, including agricultural instruction, offered the country's overwhelmingly rural population opportunities for economic and social advancement. Both the Mandate and the more powerful post-independence administrations, viewed teaching agriculture as a way to develop the country while limiting the dangers of a more academic education in terms of fomenting rebellions. As a result, the elementary school syllabi included agriculture, but it was also substituted for religion as an exam topic in primary schools for non-Muslim students ${ }^{42}$. Village elementary schools taught practical agriculture rather than the English language, "to give the village pupils an orientation in manual work in agriculture in order to be better prepared to accept village life" ${ }^{43}$. Village life presumably would not require instruction in English, a language reserved for government bureaucrats and secondary school teachers. Agriculture was taught in the (few and urban) secondary schools for two periods per week ${ }^{44}$.

In the 1950s, King Abdullah and a cadre of Mandate-era officials continued to view agricultural instruction as a way of limiting social mobility and

39 Government of Palestine Department of Education, Elementary School Syllabus: Revised Edition, Jerusalem, 1925, p.70.

40 Government of Palestine Department of Education, Department of Education Annual Report, 19281929, Jerusalem, 1930, p. 9.

41 Abdul Latif Tibawi, Arab Education in Mandatory Palestine, op. cit., p. 245-246.

42 Ahmad Yousef Al-Tall, Education in Jordan: Being a Survey of the Political, Economic and Social Conditions Affecting the Development of the System of Education in Jordan 1921-1977, Islamabad, National Book Foundation, 1979, p. 62.

43 Ibid. p. 74.

44 Ibid. p. 75. 
urbanization, thereby counteracting policies inducing peasants to leave farming $^{45}$. Jordan depended on foreign aid and faced a huge influx of Palestinian refugees. For the government, agricultural education represented a way to keep the country's growing population, both Jordanian and Palestinian Jordanian from rebelling. Government policies aimed at sending students to agricultural schools (at home and abroad), while increasing their desire for rural life, respect for manual labor and self-reliance ${ }^{46}$. Through the end of the 1950s, students in the fourth through sixth year of primary school spent one period a week on "agricultural activities" in addition to working in school gardens ${ }^{47}$. The total number of elementary schools grew from 77 in 1946 to 1519 in $1960^{48}$. Increased access to education meant, however, more opportunities for social mobility; as a result the government increasingly feared the emergence of new, educated elites, both Jordanian- and Palestinian-born ${ }^{49}$.

Beyond agricultural instruction in lower-level government schools, rural teachers' training centers, across Palestine, Iraq and later Jordan devoted still more time to practical and theoretical agriculture, while guaranteeing a job behind a desk rather than a plow. Centers aimed at training village teachers to improve agriculture, and rural schoolchildren's health. These teachers would, according to their governments, return to their villages rather than gravitate to the city. Governments sought to stem the tide of rural migrants to urban areas; when conditions for farmers deteriorated, cities offered (often false) promises of employment. Potentially volatile slums in Baghdad, Basra and eventually Haifa spurred government fears of rebellion ${ }^{50}$. Rural training centers were meant to expand education, while reinforcing an urban/rural divide. Still, becoming a village teacher guaranteed a steady salary and a way out of sharecropping, naturally leading to shifts in the social lives of villages as well.

Iraq's Rural Teachers' College, established 14 kilometers south of Baghdad in 1934, helped Iraqis who were unable to attend more academic institutions

45 "Nomads, Peasants and the State in Jordan: the Politics of Rural Policy", art. cit., p. 96-98.

46 Jordan Wizarat al-Tarbiyah wa-al-Talim, Al-Taqrir Al-Sanawi 1958-1959-Wizarat all-Tarbiyah Wa-alTa 'lim, Amman, Wizarat al-Tarbiyah wa-al-Ta 'lim, 1959, p. 215; “The politics of rural policy”, art. cit. p. 96.

47 Ahmad Yousef Al-Tall, Education in Jordan, op. cit., p. 75.

48 Ibid.

49 Ibid., p. 106.

50 Isam al-Khafaji, Tormented Births: Passages to Modernity in Europe and the Middle East, London, I.B. Tauris, 2004, p. 171-182. 
gain a foothold as teachers in the civil service. The three-later five-year course of study involved six hours per week of "practical and theoretical training in agriculture" in addition to first aid and hygiene. In the later years of the course, students learned dairying, poultry breeding, and pedagogy. One of these rural institutes included a government farm. Enrollment at the rural institutes ranged from a few hundred to more than 1,000 at a time, during the 1930s and 1940s. The Iraqi government hoped to entice poorer, rural students to these institutions, by paying students' tuition as well as room and board. Rural teachers' training centers were relatively more popular than purely agricultural colleges as students became teachers, not agriculturalists, after graduation. In the mid1940s, the staff and instructors of the schools had little agricultural training, indicating that the course prepared better teachers than tillers of the land ${ }^{51}$.

Like its' Iraqi and Jordanian counterparts, the government of the Mandate for Palestine's rural teacher training center intended to train village teachers to improve village life. The Palestinian institution, founded in 1936 in Ramallah, admitted only women, in order to alleviate the shortage of female teachers in rural areas. Indeed the limited number of educated women in the Mandate for Palestine were frequently from towns, often Christian, with little desire to work in rural, often Muslim majority areas ${ }^{52}$. By 1940, when a third year was added to the school's course, it had 25 students, studying "women's agricultural occupations" in addition to "child-welfare, house management and general village hygiene" ${ }^{53}$. A former Director of Education praised the center as having adapted the elementary school curriculum to

"suit the needs of the peasant wife and mother-to-be. In addition to elementary school subjects, the girls were taught gardening, the cultivation of vegetables, poultry-rearing, bee-keeping and the like... stress was laid on needlework, laundry, cooking, baby welfare and the care of the home"s4.

51 Roderic D. Matthews, Matta Akrawi, Education in Arab Countries of the near East, op. cit., p. 184-186.

52 Abdul Latif Tibawi, Arab Education in Mandatory Palestine, op. cit., p. 230; Ela Greenberg, Preparing the Mothers of Tomorrow: Education and Islam in Mandate Palestine, Austin, University of Texas Press, 2012, p. 62-63.

53 Government of Palestine, "The Unpublished Mandate Report for the Year 1940" in Palestine and Transjordan Administration Reports, 1918-1948, Slough, Archive Editions, 1995, p. 11.

54 Humphrey Ernest Bowman, Middle-East Window, London, Longmans, Green, 1942, p. 277. Bowman cites domestic science as the preserve of peasant women; Sherene Seikaly's book describes Palestine's middle class; its' bourgeois values of thrifty, moral consumption required knowledge of domestic science. Sherene Seikaly, Men of Capital: Scarcity and Economy in Mandate Palestine, Stanford, Stanford University Press, 2016, p. 53-65. 
According to the former Director, the school improved health and hygiene by producing ideal peasant women: lower-class teachers, who would subsequently become as well as train thrifty, modern, wives and mothers. However, local demand for new schools meant that graduates found ready work as teachers, and often postponed marriage ${ }^{55}$. Extant personnel files on graduates of the center indicate students came from urban as well as rural areas and that they taught in both. Of the eighteen personnel files that remain, fifteen teachers were born in more urban areas, and only eight taught in rural areas during their careers ${ }^{56}$. Still, the emphasis on manual training tended to impede girls' advancement even in education, as Mandate Palestine's educational system prized English-language skills over domestic prowess. Government officials emphasized the value of practical training for village women. However, the Rural Training Institute's poor academics meant several graduates were not qualified for classified teaching posts, forcing them to become "unclassified" teachers ${ }^{57}$. Then again, the Rural Training Center allowed more of the female village population to attend school and to earn a living. After 1948, the Jordanian government incorporated this institution into its educational system, but as a purely academic institution.

Conversely, Jordan created a training center for rural male teachers during the 1952-1953 school year. Its graduates were meant to "raise the level" of the villages to which they were assigned. Their course of study included practical agriculture (working in the institute's field), agricultural instruction, raising poultry and rabbits, studying animal and plant illnesses (and their prevention) as well as bi-weekly village visits, to learn about local issues, and to try to solve them ${ }^{58}$. The Ministry of Education's 1956 report proclaimed the school was

55 Great Britain Palestine Royal Commission, "Palestine Royal Commission: Minutes of Evidence Heard at Public Sessions with Index", London, His Majesty's Stationery Office, 1937, p. 355.

56 The following teachers were born in urban areas: the first five taught in rural areas; "Saniya Zu'bi I'bilin Girls School", Israel State Archive ISA, Jerusalem, Israel, 1038/18 M; "Din Hasan Sa'id” ISA 1039/4 M; "Da'd Aqil Girls School" 1043/5 M; "Balqis Ghannoum" ISA 1039/28 M; "Budur Hijazi Girls School" 1043/7 M; "Balqis el-Sheikh Tarshiha Girls School" ISA 1035/9 M; "Shahira Qaddura Haifa Girls School " ISA 1039/14 M; "Amineh Hijazi" ISA 1040/15; "Hayat Mansour Girls School" ISA 1039/5 M; "Khadijeh Kilani Acre Girls School" ISA 1039/12 M; "Nijmeh Ukasha Girls School" 1040/13 M; "Fatima Khazairan" 1042/20 M; "Maryam Khamis Girls School" ISA 1045/25 M; "Fayiza el-Masri Girls School" ISA 1045/38 M; "Aliya Mughrabi Girls School" ISA 1048/15 M; "Nazmiya Hassoun" 1040/14 M; "Amineh Hijazi" 1040/15; "Shahira Gaddura Haifa Girls School "ISA 1039/14 M. The following teachers were born, and taught in villages: "Rabi'a Qutaifan Girls School" ISA 1039/15 M; "Fatma Dan Girls School" ISA 1047/3 M; "Alia Abu Humeida Tarshiha Girls School” ISA 1033/14 M. "Saniya Zu'bi I'bilin Girls School” ISA 1038/18 M, "Balqis Ghannoum” ISA 1039/28 M.

58 Jordan Wizarat al-Tarbiyah wa-al-Ta lim, Al-Taqrir Al-Sanawi 1955-1956-Wizarat Al-Tarbiyah Wa-AlTa lim, Amman, Wizarat al-Tarbiyah wa-al-Ta lim, 1956, p.9, 10. 
to reform small villages in rural Jordan, and that teachers would play a key role promoting modern education and improving the lives and awareness of villagers. In addition "practical" agricultural training, students had to learn all academic subjects, up to the level of a high school equivalence ${ }^{59}$. The emphasis on practical training notwithstanding, the school itself was explicitly geared towards the production of teachers. These teachers were not to farm the land themselves, but rather to instruct villagers on how to do so, while addressing a myriad of other social and economic problems in the villages.

Few students attended rural training centers during the Mandate period, although their numbers increased during the 1950s and 1960s. There are few references to the effects of these graduates on agriculture. Rather, every graduate escaped the fate of their families and their communities, becoming teachers rather than fellahin ${ }^{60}$. The following section analyzes the type of agricultural work village teachers were expected to perform, specifically the supervision of school gardens. School gardens were well known in Iraq and widespread in Palestine and Transjordan. They also mark the broadest contribution of the Mandate governments to Arab agricultural education.

\section{School Gardens}

From the interwar period through the 1950s, school gardens became a familiar feature of education throughout the Middle East. An offshoot of the $19^{\text {th }}$-century global nature study movement, school gardens worldwide were meant not only to improve students' well-being, but also to increase political stability, by assimilating immigrants in urban slums ${ }^{61}$, or by encouraging children to remain "agricultural laborers" 62 . However, in Britain's Middle Eastern Mandates, having a garden at school failed to convince either students or their parents of the desirability of farming.

59 Ibid, p. 10.

60 This expands Sherene Seikaly's discussions of family in Mandate Palestine; she portrays static class categories, emphasizing the "construction of class difference" rather than attempts within individual families to better themselves. Sherene Seikaly, Men of Capital, op. cit. p. 54.

61 Brian Trelstad, "Little Machines in Their Gardens: A History of School Gardens in America, 1891 to 1920", Landscape Journal, vol. 16, no. 2, 1997, p. 170.

62 Howard A. Fergus, A History of Education in the British Leeward Islands 1838-1945, Kingston, University of the West Indies Press, 2003, p. 145-147. 
A report by the British Mandate Government of Palestine to the League of Nations in Palestine idealized village school gardens as places where "the pupils, who are to form the next generation of cultivators, are taught simple farming practice under the supervision of Government instructors"63. The British-run Department of Agriculture in Palestine added, "we hope to give elementary but very practical teaching in the planting of fruit-trees and vegetables, poultry-breeding, etc." ${ }^{64}$. Ideally, this "very practical teaching" would keep elementary school students as productive laborers in rural areas ${ }^{65}$. School gardens offered detailed instruction in agricultural practices on a small scale. In the gardens of Palestine, for instance, students, possessing their own plots in higher grades, learnt terracing as well as how to plant and cultivate a variety of crops, plying "steel ploughs, harrows, hoes, cultivators, shovels, wheelbarrows" 66 in order to grow vegetables, fruit trees and cereals ${ }^{67}$. Depending on the schools' resources, students might also study bee keeping and poultry raising.

The number of school gardens varied, according to policymakers' goals and funding availability. Iraq had the fewest school gardens of the three areas, due to the academic emphasis its curricula. By the late 1940s, an unspecified number of "new model farm schools" in Iraq included attached gardens, where graduates of Iraq's School of Agriculture taught hands-on methods to elementary school children ${ }^{68}$. A former student in al-Majer al-Kaber praised his elementary school's farm and garden that "supplied the city with milk, chickens and eggs" Conversely, in Transjordan, by the end of the Mandate period, nearly half of village schools had school gardens ${ }^{70}$. By the end of the 1950s, Jordan's school

63 Great Britain Colonial Office and the Council of the League of Nations, Report by His Majesty's Government in the United Kingdom of Great Britain and Northern Ireland to the Council of the League of Nations on the Administration of Palestine and Trans-Jordan for the Year 1932, 1932, p. 27.

64 Permanent Mandates Commission League of Nations, "Minutes of the Twenty-Second Session, Held at Geneva from November 3rd to December 6th, 1932, Including the Report of the Commission to the Council", Geneva, 1932.

65 The British feared the growth of educated, articulated nationalists who would foment revolutions against them. See for example, Lucie Ryzova, The Age of the Efendiyya, op. cit., p. 42.

66 "British Agricultural-Educational Institutions in Mandate Palestine and Their Impress on the Rural Lanscape", art. cit. p. 101.

67 Roderic D. Matthews, Matta Akrawi, Education in Arab Countries of the near East, op. cit., p. 245.

68 Ibid., p. 157. These schools are not mentioned in the report of the Ministry of Education in the same year.

69 Dr. Abdul Amir Al-Aboud, Iraq: A Minister's Memoir, trans. Abdul Amir al-Aboud, Author House, 2015, p.9.

70 A. Al-Tall, Education in Jordan, op. cit. p. 306, 310. 
gardens had increased from 34 to 186, although the number of government schools grew far more: from 74 to $971^{71}$. Similarly, in Palestine, over half of government elementary schools, in both towns and villages had school gardens: the number of gardens increased from 209 to 248 between 1936 and 1946, the number of elementary schools from 380 to $509^{72}$.

Transjordan's official reports painted a rosy picture of the growth in number of school gardens. Convincing local children and villagers to benefit from (or not destroy) these agricultural initiatives was more difficult. In 1932, the Director of Education wrote that every principal or teacher must have a garden for his or her school, in order to practice agriculture. Principals and teachers were required to report to the Ministry of Education the number and type of plants within the garden ${ }^{73}$. Concern for these initiatives, can be seen in the Director of Education's warning to the principal of the school of Kura that the new plants in the school garden, which had been "grown through great efforts," were "vulnerable during school holidays to acts of sabotage or vandalism by locals". The Director of Education required the school's staff to record all of the plantings, sharing their list with the local headmen and elders, "so that if there is even the slightest shortage" then the community and government would know ${ }^{74}$. Locals did not always support the gardens (or the government). For example, one letter notes that villagers used a well earmarked for a school garden for themselves ${ }^{75}$. Despite this uneven process of implementation, school gardens remained a feature of Jordanian education through the end of the 1950s.

The impact of school gardens on agricultural practices, and concurrently the development and modernization of villagers is difficult to measure. Sources criticizing the situation reflect more local and foreign academics' views of ideal education, rather than the situation on the ground. For example, Roderic Matthews and Matta Akrawi's report on education in the 1940s criticized cur-

71 Al-Taqrir Al-Sanawi 1958-1959, p. 10, 61.

72 Department of Education Government of Palestine, "Annual Report for the School Year 1936-1937", Jerusalem, 1938, p. 34; Education in Palestine: General Survey 1936-1946, Jerusalem, 1946, p. 10; Department of Education Government of Palestine, Department of Education Annual Report 19451946 , p. 6.

73 "Communication number 32 from the Director of Education to the Principal of the school of Kura", National Library of Jordan (NLJ) 2/6/5/22, August 23, 1932.

74 "Communication 7, from the Director of education to the Principal of the school of Kura", NLJ, 1/6/5/22, March 30, 1932.

75 "Letter from the director of the district of Kura to the commander of the station at Kura, subject: The Wells of the School Gardens", NLJ, 69/6/1/33, October 7, 1936. 
ricula throughout the region as "bookish and academic, borrowed from abroad, and designed to prepare for the passing of examinations". The report lauded the spread of school gardens, especially in Palestine, but noted "little sign of any attempt to tie up the activities of the school with those of the community"76. Abdul Latif Tibawi, a student in the schools of Mandate Palestine, a former Inspector of Education and historian, summarized Matthews and Akrawi's argument: "agricultural instruction in schools was not in the opinion of the writers, bearing fruits (sic) in the form of tangible social advance in the village life." Teaching agriculture and gardening to a few nine to eleven years-old boys, "sons of farmers, practically familiar with the subject and accustomed quite early in their life to all types of agricultural labor..." could not affect change, “... at any rate not [change] of such depth as to show itself in the improvement of the methods of farming"77. Yet, in Palestine, some families provided land for the school gardens, which indicates a degree of local enthusiasm for the projects ${ }^{78}$.

Bureaucratic turf wars, and frustration at the political and economic situation in rural areas overall seem to have muted the effects of school gardens ${ }^{79}$. As a former student in a rural school in Palestine argued the

"peasants, being ignorant and heavily taxed, were not very much impressed with the scheme of school gardens. Their children also, due to the meagre training and to their parent's desperate economical situation attempted to neglect the soil and migrate to the cities seeking jobs" ${ }^{" 00}$.

Most probably, agricultural instruction within schools did not substantially alter farming practices. Agricultural colleges, however, offered "tangible social advance [ment]" for students, albeit not necessarily in the ways each government intended.

\section{Agricultural Colleges}

Despite the Mandate governments for Iraq and Palestine, and the post-Mandate governments of Iraq and Jordan's stated goals, each state supported agricultural

76 Roderic D. Matthews, Matta Akrawi, Education in Arab Countries of the near East, op. cit., p. 546.

77 Ibid., p. 235-236.

78 Roza El-Eini, Mandated Landscape, op. cit., p. 152.

79 B.A. Keen, The Agricultural Development of the Middle East, London, H.M.S.O, 1946, p. 41.

80 Abdulqadir Mohammad Yousuf, The British Educational Policy in the Arab Public Schools of Palestine, op. cit., p. 159-160. 
institutes that trained teachers and officials rather than farmers. Iraq's agricultural college proved a poor experiment until the 1960s, failing to provide white-collar jobs (or indeed any jobs) to its graduates. In Palestine, political and practical troubles reduced the college's effect on agriculture, although its students found work as teachers and agricultural experts. Jordan did not have institutions devoted to agriculture until the 1950s, inheriting Palestine's agricultural college along with the West Bank, and founding new institutions in suburbs by the late $1950 \mathrm{~s}^{81}$. The Jordanian government took care to employ these institutions' graduates as civil servants, fearing, as the British had before them, that a glut of the educated unemployed would lead to political instability.

The Iraqi School of Agriculture's rather ineffective history began in 1921 when the government approved funds for the college building in hopes of filling the country's "need for local personnel trained in modern agricultural science" ${ }^{\prime 2}$. Although the building was finished by 1923, there was nowhere for students or teachers to live nearby, which prevented the college from opening. In 1926 Iraq's parliament agreed to fund the construction of living quarters for the college; the school opened, with tents for students before construction was finished. Iraq's government had intended the college to provide a post-secondary course of study in modern agriculture. The government even went so far as to pay students' tuition and board in order to entice them to matriculate. The school comprised a three-year course of education beyond the intermediate level, including Arabic, English, "practical agriculture", organic chemistry, irrigation, dairying, agricultural machinery, and chicken-breeding" 83 .

Designed to encourage the sons of landowners and tribal leaders to modernize agriculture, the college attracted boys seeking government employment. In 1929, the Ministry of Education asserted the college's purpose was "to increase those who are familiar with the foundations of modern agriculture in order to help... in the farms and not in order to create employees" 84 . As a degree from the college did not always result in a government job, it only drew students from the Teachers' Training College in Baghdad, which promised

81 Jordan Wizarat al-Tarbiyah wa-al-Ta lim, Al-Taqrir Al-Sanawi 1953-1954-Wizarat Al-Tarbiyah Wa-AlTa 'Lim', Amman, Wizarat al-Tarbiyah wa-al-Ta'lim, 1954, p. 2.

82 Roderic D. Matthews and Matta Akrawi, Education in Arab Countries of the near East, op. cit., p. 179.

83 Ibid.

84 Wizarat al-Ma`arif Iraq, Al-Taqrir Al-Sanawi`an Sayr Al-Ma`arif 1928-1929, Bagdad, Wizarat al-Ma`arif, 1929, p. 27. 
students government posts ${ }^{85}$. In 1932, a combination of language conflicts (teaching in English was too difficult for the students, teaching in Arabic likewise for the often foreign professors) primarily foreign textbooks, and lack of interest, resulted in the college's closure. A rural teachers' training college, whose graduates were assured a government post, took over the building. The Agricultural College reopened in the mid-1930s ${ }^{86}$. By 1945, the school could accommodate 200 students; less than half of that number actually attended. This indicates a lack of interest despite continued incentives of free tuition, room and board. As Matthews and Akrawi noted, "Apparently there is little demand for trained agriculturists except in government employment where vacancies are fewer than applicants" ${ }^{87}$. If graduates of agricultural schools were unable to find employment, they could not put their new knowledge into practice, as they owned noland of their own ${ }^{88}$. However, the few students who graduated from the Agricultural College in the 1940s evidently gained positions in government employment: the Ministry of Agriculture or the Ministry of Education employed all but one of the 48 graduates in $1945^{89}$.

By the early 1950s, there was a proposal to distribute agricultural lands to college graduates in the hopes of convincing them to become farmers. However, as an article in a local paper, AlZaman noted, "It is unfortunate that the Ministry of Education during its 30 years in existence has been 'a factory for producing government employees only"' ${ }^{\prime \prime}$. Into the 1950s, agricultural education remained unpopular: only $31.67 \%$ of surveyed Iraqis desired agricultural education, $44 \%$ were positive towards vocational schooling, and $80 \%$ preferred general education from the government ${ }^{91}$.

As in Iraq, the few agricultural schools sponsored by the Mandate Government in Palestine tended to train teachers rather than farmers. The pinnacle of Arab agricultural education in Palestine and Transjordan from the Mandate period through the 1950s was the Kadoorie Agricultural School. The bequest of Sir

85 Roderic D. Matthews and Matta Akrawi, Education in Arab Countries of the near East, op. cit., p. 193.

86 The Iraq Government Gazette, no. 22, May 31, 1936, p. 304.

87 Education in Arab Countries of the near East, p. 178-179.

88 Mahir Qaysi, Youth Education in Iraq and Egypt, 1920-1980: A Contribution to Comparative Education within the Arab Region, Tarbiyat Al-Shabab Fi Al-'Iraq Wa-Misr, 1920-1980, Helicon, 1983, p. 55.

89 Education in Arab Countries of the near East, p. 179.

90 The Iraq Times, no. 10 467, January 6, 1953.

91 Victor Clark, Compulsory Education in Iraq, Paris, UNESCO, 1951, p. 135. 
Ellis Kadoorie, an Iraqi Jew established the college, which opened in 1931 in the rapidly growing town of Tulkarm. This bequest also funded a Jewish Kadoorie School at Mt. Tabor, after both the Arab and Jewish communities rejected an alternative proposal to found only one institution ${ }^{92}$. The object of both Kadoorie schools was, "to provide practical courses of agriculture... so that when the students return to their own lands they may not only develop their own farms, but encourage the adoption of improved farm practices..." ${ }^{93}$. The syllabus of the Arab college included a variety of specialized subjects: agricultural zoology, bacteriology, crop rotation, farm accountancy, cooperation and marketing, horticulture and forestry, stone fruits, orchard irrigation, vegetable farming, tropical fruits, forest conservation, and other subjects ${ }^{94}$.

Despite its farming-oriented curriculum, only three or four graduates of the school actually worked on farms. While a few became inspectors for the department of agriculture, the majority worked as teachers, making their way up through the civil service ${ }^{95}$. For example, Fuad Assad Gaddura attended the Kadoorie School, worked as a teacher, and eventually transferred to a better post in the Forestry Department of the Mandate for Palestine ${ }^{96}$. The Kadoorie School was meant to admit a majority of rural Arabs as stated in the 1930 report to the League of Nations, "sons of landowners or practical farmers were given preference in all cases" ${ }^{\prime \prime}$, however, "many town students without land property and sometimes without interest in the field" were also admitted. The principal and instructors at the college represented some of the more elite families in Palestine ${ }^{98}$. Kadoorie's principal attempted to dissuade government job seekers from attending; he wrote aspiring students in 1937 that the goal of the school was agricultural training, improving students' and their families' land rather

92 “Subject: Sir Ellis Kadoorie’s Bequest” 28 July 1931. National Archives, Kew, United Kingdom NA, Ag/15/AT 101/1013, CO 733/376/6. 1, Education in Jordan.

93 Palestine Royal Commission, p. 27.

94 The Department of Agriculture, Mandate for Palestine. "The Syllabus of the Kadoorie Agricultural School" Government Press, Jerusalem, 1931. NA T101/1013, p. 2.

95 Roderic D. Matthews, Matta Akrawi, The British Educational Policy in the Arab Public Schools of Palestine, op. cit., p. 195-196.

96 "Fuad Assad Qaddura Shafa 'Amar" ISA 1037/18 M.

97 Palestine and Transjordan Administration Reports, 1918-1948: Vol. 3, 1929-1931, 16 vols, Slough, Archive Editions, 1995, p. 130.

98 Government of Palestine, Staff List of the Government of Palestine as on the 1st August, 1945 Jerusalem, 1945; Sami M. Moubayed, Damascus between Democracy and Dictatorship, Lanham [Md.], University Press of America, 2000, p. 26; Government of Palestine, Civil Service List, Staff List of the Government of Palestine 1939, Jerusalem, 1939. 
than their careers in bureaucracy ${ }^{99}$. However, Kadoorie became a training center for rural educators. Thus, another Mandate-era institution meant to train enlightened farmers in fact produced teachers, who in turn joined the ranks of the civil service ${ }^{100}$.

In Transjordan and Jordan, specialized agricultural education was limited, due to a lack of funding as well as its unpopularity. Jordan's Ministry of Agriculture founded several agricultural institutions, from the preparatory to the college level in the mid-1950s. Yet, the only way to convince students to go to agricultural rather than academic secondary schools was either to restrict admission to non-vocational institutions or to offer students white-collar jobs as well, which -in the government's-view would defeat the purpose ${ }^{101}$. Through the end of the 1950s, the Jordanian Government adopted the latter tactic. Approximately 50 teachers graduate from the Kadoorie School which was integrated Jordan's educational system after 1948 and began teaching before 1958. Many of them obtained high-ranking posts, becoming principals of schools, inspectors of school gardens or even heads of department ${ }^{102}$. A degree from an agricultural school counted as an academic degree, enabling its students to start with a higher paygrade in the government civil service and to advance from there.

Victor Clark, an American researcher in Iraq in the 1950s noted policymakers in Iraq's educational system had paid little attention to the perhaps insurmountable economic and social problems facing the majority of Iraqis. As Clark put it, those who advocated compulsory education as a way of improving agriculture, "functionally divorced the social force of education from other social forces which were actually governing the dynamics of Iraqi life" ${ }^{103}$. Whether or

99 "Letter from the principal of Kadoorie Agricultural School, Tulkarm to prospective entrants", July 1937, ISA 27-2630/G358, quoted in Ylana N. Miller, Government and Society in Rural Palestine, 1920-1948, Austin, University of Texas Press, 1985, p. 110, 189.

100 Abdul Latif Tibawi, Arab Education in Mandatory Palestine, op. cit., p. 51.

101 Dairat al-Matbu 'at wa-al-Nashr Wizarat al-Thaqafah wa-al-I'lam, Al-Urdun Fi Khamsin `Amm, 19211971', Amman, Maṭba'at al-Istiqlāl al-'Arabī, 1972, p. 141, 152.

102 Idārat al-mawārid al-basharīyah, Qism al-Arshīf, Wizārat at-Tarbiya wa-'t-Ta'tīm, al-Mamlakah al-Urdunīyah al-Hāshimìyah, Amman, Wizārat at-Tarbiya wa-'t-Ta'lìm, al-Mamlakah al-Urduniyah al-Hāshimìyah, 2013; The Human Resources Department, Archive Section, the Ministry of Education of the Hashemite Kingdom of Jordan. HRD. "Basim "Ali Muhammad al-Jarbawi" 0002014, "Salim "Abd al-Rahman 'Arafat” 0002464.

103 Victor Clark, Compulsory Education in Iraq, op. cit., p. 19-20. 
not agricultural education improved Iraqi, Palestinian and Jordanian society, those who were able to gain access to education improved themselves. Through education, villagers joined the civil service, becoming teachers in rural areas rather than farmers as a way of ensuring a regular paycheck ${ }^{104}$. Across the region, the Mandates, and into the transition from colonial to post-colonial states, education offered a means of social mobility: the lucky few who obtained any schooling beyond a secondary, or even an elementary level gained a clear path to government service. Those who went to elementary schools, worked in school gardens, and attended higher institutes of agricultural learning in the Mandates were able to gain a foothold in the civil service; very few it seems were content to return to their farms.

\section{Hilary Falb Kalisman}

Université de Colorado Boulder, Boulder, États-Unis hilary.kalisman@colorado.edu 